\title{
Prognostic value of monocyte and neutrophils to lymphocytes ratio in patients with metastatic soft tissue sarcoma
}

\author{
Long Jiang ${ }^{1,2,3,4, *}$, Shanshan Jiang ${ }^{1,2,3, *}$, Dongrong Situ ${ }^{1,2,3, *}$, Yongbin Lin ${ }^{1,2,3}$, \\ Han Yang ${ }^{1,2,3}$, Yuanfang $\mathrm{Li}^{1,2,3}$, Hao Long ${ }^{1,2,3}$, Zhiwei Zhou ${ }^{1,2,3}$ \\ ${ }^{1}$ Sun Yat-sen University Cancer Center, Guangzhou, China \\ ${ }^{2}$ Collaborative Innovation Center for Cancer Medicine, Guangzhou, China \\ ${ }^{3}$ State Key Laboratory of Oncology in South China, Guangzhou, China \\ ${ }^{4}$ University of California, San Francisco, CA, USA \\ *These authors have contributed equally to this work \\ Correspondence to: \\ Zhiwei Zhou, e-mail: zhouzhw@sysucc.org.cn \\ Hao Long, e-mail: longhao@sysucc.org.cn
}

Keywords: soft tissue sarcoma, metastasis, immunity, prognosis

Received: December 23, 2014

Accepted: February 05, 2015

Published: March 20, 2015

\section{ABSTRACT}

Metastatic soft tissue sarcomas (STS) represent enormous challenges to improve the low survival rate, which is almost the same as past 2 decades ago. Prognosis of cancer patients are based not only on tumor-related factors but also on host-related factors, particularly systemic inflammatory response. We evaluated the association among possible risk factors and survival for metastatic STS by reviewed a singleinstitution nearly 50-year experience. We found that both monocyte ratio and NLR ratio were significant prognostic predictors for OS and PFS of metastatic STS. And patients with monocyte ratio or NLR ratio > 1 should be screened out as candidates for more intensive or aggressive multimodality treatments and more aggressive followup. For this reason, this result could serve as a basis for future prospective study.

\section{INTRODUCTION}

Soft tissue sarcomas (STS), arising from almost any embryonic mesodermal tissue, account for nearly $1 \%$ of newly diagnosed malignancies annually [1]. Under multimodality treatment, patients with localized disease have estimated 5-year survival rates of about $70 \%$ [2-4]. However, metastatic STS, constituting approximately $40 \%$ of metastatic osteosarcoma and also the second most common cause of pulmonary metastatic disease, still represent enormous challenges to improve the low survival rate $[5,6]$. Despite advances in chemotherapy, radiation therapy and surgery, the three year survival of patients with metastatic sarcoma is $20-45 \%$, which is almost the same as past 2 decades ago [6-9].

Nowadays, increasing data indicated that prognosis of cancer patients are based not only on tumor-related factors but also on host-related factors, particularly systemic inflammatory response $[10,11]$. As a significant indicator patients' inflammation status, neutrophil/ lymphocyte ratio (NLR) was proved as an predictor of prognosis in colon cancer, lung cancer, and liver cancer [12-16]. Increased counts of neutrophils and/or decreased counts of lymphocytes might serve as suppressor of lymphokine-activated killer cells, which could increase the propensity to metastasis [17]. Recent studies have illustrated that circulating monocyte count could be an independent risk factor of poor prognosis in various cancers $[18,19]$.

Our aim of this study is to determine whether possible risk factors (age, sex, size of primary tumor, tumor depth, pathological subtypes, pathological grade, monocyte ratio and NLR ratio) were associated with survival for metastatic STS.

\section{RESULTS}

142 of 154 patients with metastatic STS were eligible for the final analysis. In this group of 142 patients, the mean age was 44.35 years (range: $5-71$ years, median 
47.5 years); 60 patients were male $(42.3 \%)$ and 82 female $(57.7 \%)$. The tumors pathological subtypes included so-called fibrohistiocytic tumors in 22 patients $(15.5 \%)$, undifferentiated sarcomas in $96(67.6 \%)$, smooth muscle tumors in $22(15.5 \%)$, and fibroblastic/myofibroblastic tumors in $2(1.4 \%)$ (Table 1$)$.

The mean follow-up for survivors as of December 2014 was 71.05 months (range: $2.97-476.17$ months,

Table 1: Clinicopathological correlation of monocyte ratio and NLR ratio and in Patients with Metastatic STS

\begin{tabular}{|c|c|c|c|c|c|c|c|c|}
\hline Characteristic & All $(n=142)$ & & $\begin{array}{l}\text { monocyte } \\
\text { ratio }<=1 \\
(n=99)\end{array}$ & $\begin{array}{l}\text { monocyte } \\
\text { ratio }>1 \\
(n=43)\end{array}$ & $P$ & $\begin{array}{l}\text { NLR ratio }<=1 \\
(n=89)\end{array}$ & $\begin{array}{l}\text { NLR ratio > } \\
1(n=53)\end{array}$ & $\boldsymbol{P}$ \\
\hline Age, yrs & $\begin{array}{l}47.5^{\dagger} \text { (range: } \\
5-71)\end{array}$ & & $\begin{array}{l}47^{\dagger} \text { (range: } \\
6-70)\end{array}$ & $\begin{array}{l}49^{\dagger} \text { (range: } \\
5-71)\end{array}$ & 0.428 & $43^{\dagger}$ (range: 6-70) & $\begin{array}{l}50^{\dagger} \text { (range: } \\
5-71)\end{array}$ & 0.368 \\
\hline Sex $(\%)$ & & & & & 0.498 & & & 0.246 \\
\hline Male & 60 & $42.30 \%$ & 40 & 20 & & 35 & 25 & \\
\hline Female & 82 & $57.70 \%$ & 59 & 23 & & 54 & 28 & \\
\hline $\begin{array}{l}\text { Primary Tumor } \\
\text { Size }(\mathrm{cm})\end{array}$ & $\begin{array}{l}5.5^{\dagger} \text { (range: } \\
0.5-20)\end{array}$ & & $\begin{array}{l}5.75^{\dagger} \text { (range: } \\
0.5-18 \text { ) }\end{array}$ & $\begin{array}{l}5.4^{\dagger} \text { (range: } \\
1-20)\end{array}$ & 0.799 & $\begin{array}{l}5.5^{\dagger} \text { (range: } \\
0.5-20)\end{array}$ & \begin{tabular}{|l}
$5.75^{\dagger}$ (range: \\
$1-17.4)$
\end{tabular} & 0.249 \\
\hline $\begin{array}{l}\text { Primary Tumor } \\
\text { Depth (\%) }\end{array}$ & & & & & 0.601 & & & 0.363 \\
\hline Superficial & 44 & $31 \%$ & 32 & 12 & & 30 & 14 & \\
\hline Deep & 98 & $69 \%$ & 67 & 31 & & 59 & 39 & \\
\hline $\begin{array}{l}\text { Pathological } \\
\text { Subtypes (\%) }\end{array}$ & & & & & 0.42 & & & 0.736 \\
\hline $\begin{array}{l}\text { So-called } \\
\text { Fibrohistiocytic } \\
\text { Tumors }\end{array}$ & 22 & $15.50 \%$ & 17 & 5 & & 14 & 8 & \\
\hline $\begin{array}{l}\text { Undifferentiated } \\
\text { Sarcomas }\end{array}$ & 96 & $67.60 \%$ & 63 & 33 & & 59 & 37 & \\
\hline $\begin{array}{l}\text { Smooth Muscle } \\
\text { Tumors }\end{array}$ & 22 & $15.50 \%$ & 17 & 5 & & 14 & 8 & \\
\hline $\begin{array}{l}\text { Fibroblastic/ } \\
\text { Myofibroblastic } \\
\text { Tumors }\end{array}$ & 2 & $1.40 \%$ & 2 & 0 & & 2 & 0 & \\
\hline $\begin{array}{l}\text { Pathological } \\
\text { Grade (\%) }\end{array}$ & & & & & 0.129 & & & 0.135 \\
\hline 1 & 9 & $6.30 \%$ & 4 & 5 & & 4 & 5 & \\
\hline 2 & 13 & $9.20 \%$ & 11 & 2 & & 11 & 2 & \\
\hline 3 & 120 & $84.50 \%$ & 84 & 36 & & 74 & 46 & \\
\hline $\begin{array}{l}\text { Follow-up } \\
\text { (months) }\end{array}$ & & & & & 0.82 & & & 0.45 \\
\hline Median & 49.38 & & 50.83 & 47.37 & & 47.56 & 51.2 & \\
\hline Range & $2.97-476.17$ & & $3.04-476.17$ & $2.97-468.9$ & & $2.97-476.24$ & $3.21-476.17$ & \\
\hline Mean & 71.05 & & 71.65 & 69.67 & & 69.8 & 73.15 & \\
\hline
\end{tabular}

${ }^{\dagger}$ Median values are listed 
median 49.38 months). The mean tumor size at diagnosis was $6.68 \mathrm{~cm}$ (range $0.5-20 \mathrm{~cm}$, median $5.5 \mathrm{~cm}$ ).

Univariate analysis showed a PFS exceeding 225 days $(p=0.003)$ as prognostic factors (Fig. 1). Age $(P=0.238)$, Sex $(P=0.783)$, size of primary tumor $(P=0.425)$, tumor depth $(P=0.484)$, pathological subtypes $(P=0.861)$ and pathological grade $(P=0.965)$ did not have any significant impact on OS (Table 2). Median OS was 2411 days and $28.2 \%$ of the patients were alive without disease, $25.4 \%$ were alive with disease,
$45.8 \%$ dies of disease, while $0.7 \%$ ( 1 patients) died from other causes (heart disease). The overall 1-, 3- and 5-year OS rates were $88 \%, 61 \%$ and $44 \%$ each, respectively (Fig. 2).

Similarly, no significant impact on PFS when analyzing with Age $(P=0.107)$, Sex $(P=0.150)$, size of primary tumor $(P=0.777)$, tumor depth $(P=0.120)$, pathological subtypes $(P=0.351)$ or pathological grade $(P=0.364)$ (Table 2). Median PFS was 225 days and the 1-year PFS rates were 33\% (Fig. 2).

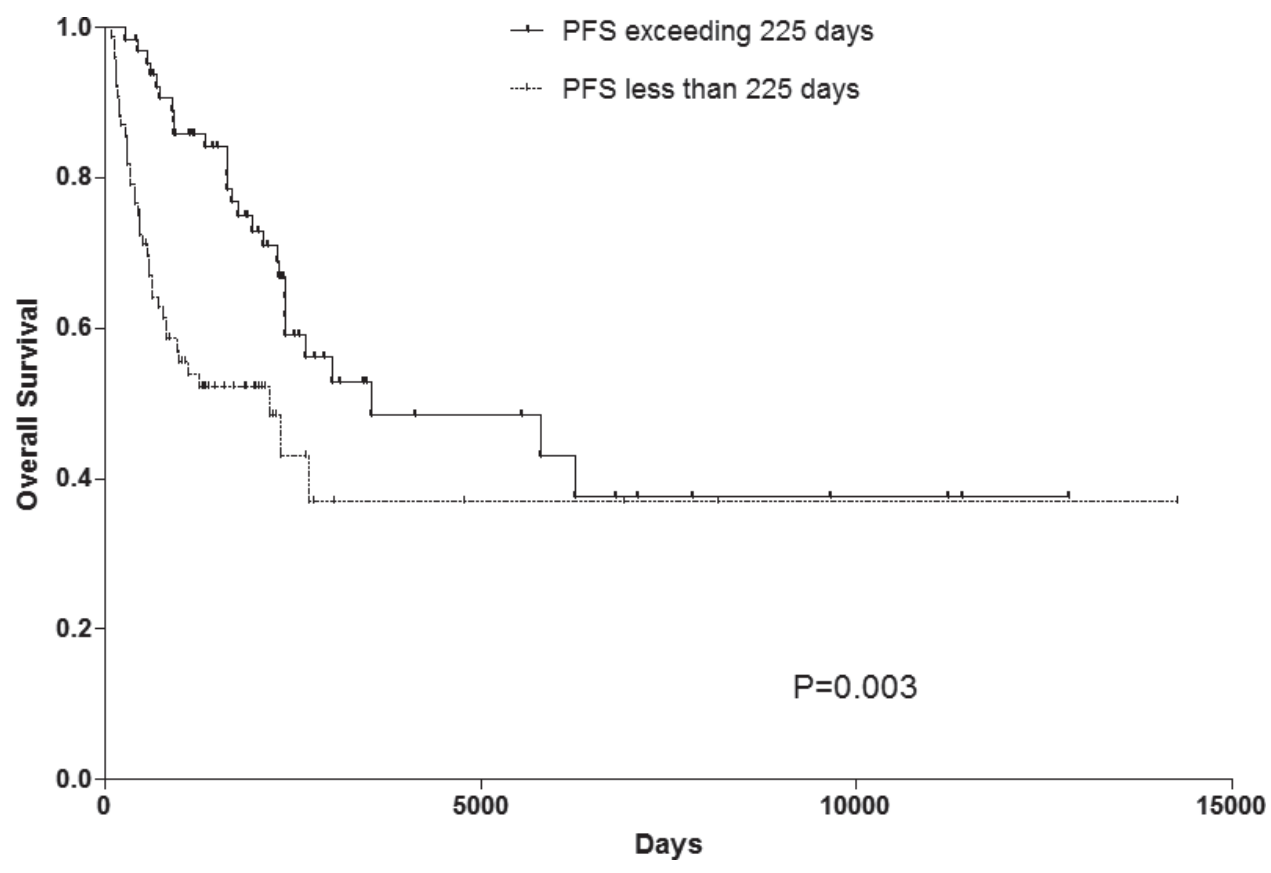

Figure 1: OS rate of patients with PFS exceeding 225 days or not. PFS progress-free survival, OS overall survival.

Table 2: Univariate analysis of prognostic factors for OS and PFS in patients with Metastatic STS

\begin{tabular}{|c|c|c|c|c|c|c|}
\hline \multirow{2}{*}{ Variables } & \multicolumn{3}{|c|}{ OS } & \multicolumn{3}{|c|}{ PFS } \\
\hline & HR & $95 \% \mathrm{CI}$ & $P$ value & HR & $95 \%$ CI & $P$ value \\
\hline Age & 1.010 & $0.993-1.027$ & 0.238 & 0.990 & $0.977-1.002$ & 0.107 \\
\hline Sex & 0.932 & $0.562-1.543$ & 0.783 & 1.298 & $0.909-1.852$ & 0.150 \\
\hline $\begin{array}{l}\text { Size of Primary } \\
\text { Tumor }\end{array}$ & 1.003 & $0.996-1.009$ & 0.425 & 1.001 & $0.995-1.006$ & 0.777 \\
\hline Tumor Depth & 1.211 & $0.708-2.069$ & 0.484 & 0.736 & $0.504-1.075$ & 0.120 \\
\hline $\begin{array}{l}\text { Pathological } \\
\text { Subtypes }\end{array}$ & 1.037 & $0.692-1.554$ & 0.861 & 0.867 & $0.687-1.123$ & 0.351 \\
\hline $\begin{array}{l}\text { Pathological } \\
\text { Grade }\end{array}$ & 1.022 & $0.392-2.661$ & 0.965 & 1.328 & $0.695-2.538$ & 0.364 \\
\hline $\begin{array}{l}\text { PFS exceeding } \\
225 \text { days }\end{array}$ & 0.476 & $0.287-0.789$ & 0.003 & & & \\
\hline monocyte ratio $>1$ & 3.085 & $1.860-5.115$ & $<0.001$ & 1.888 & $1.287-2.770$ & 0.001 \\
\hline NLR ratio $>1$ & 3.347 & $2.025-5.533$ & $<0.001$ & 1.778 & $1.234-2.562$ & 0.002 \\
\hline
\end{tabular}



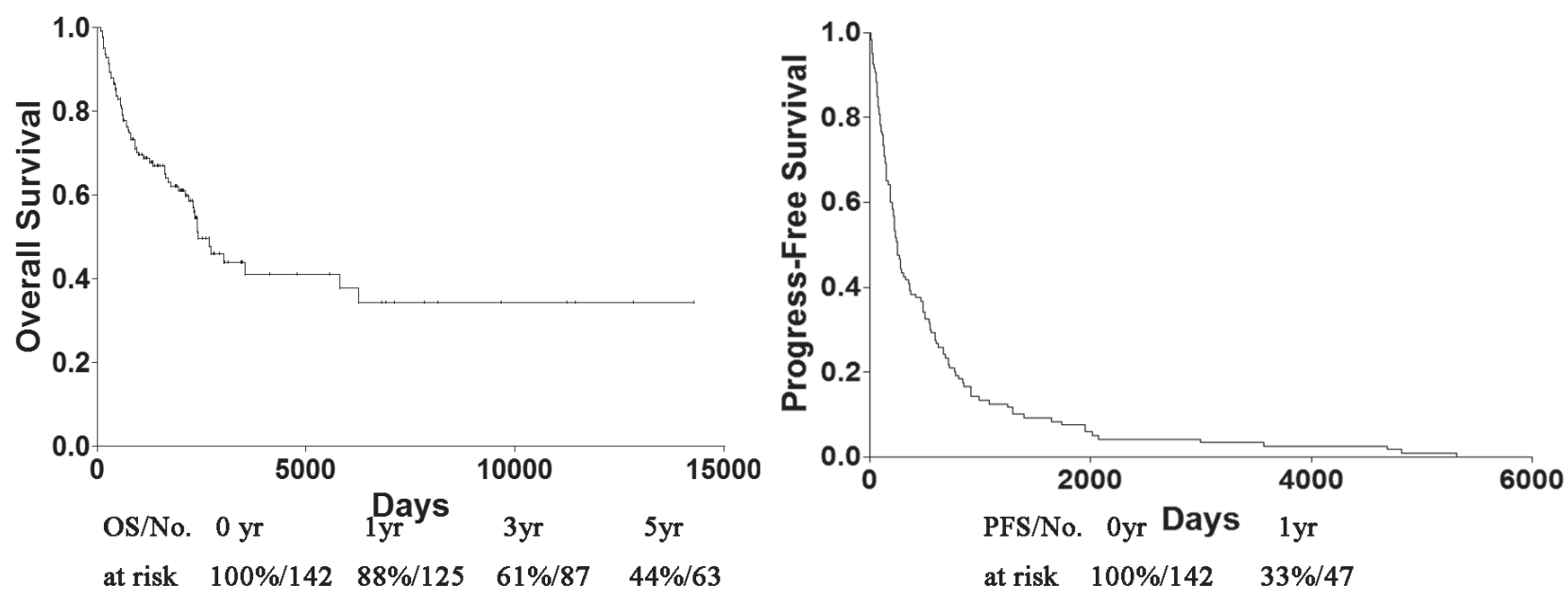

Figure 2: OS and PFS of patients with metastatic STS. PFS progress-free survival, OS overall survival.

OS was significantly worse in the monocyte ratio $>1$ group (median OS 625 days) than the monocyte ratio $<=1$ group (median OS 3544 days) $(P<0.001)$. Similar results could also be observed in the NLR ratio $>1$ group (median OS 737 days) and NLR ratio $<=1$ group (median OS 3544 days) $(P<0.001)$. Patients with monocyte ratio $>1$ had a significantly worse PFS (median PFS 135 days) than those with monocyte ratio $<=1$ (median PFS 274 days) $(P=0.001)$ and NLR ratio $>1$ group (median PFS 141 days) and NLR ratio $<=1$ group (median PFS 283 days) $(P=0.002)$. The OS and PFS curves for the two groups are shown in Fig. 3.

Due to the reason that NLR is also an independent prognostic factor for some diseases, such as coronary artery disease (CAD), hypertension, diabetes and cerebrovascular disease. The effect of those diseases were evaluated on both NLR group and monocyte group (Supplemental Table S1).

Results of multivariable analysis to identify prognostic factors for OS and PFS in Metastatic STS patients are shown in Table 3. In multivariable analysis, the presence of NLR ratio $>1$, and monocyte ratio $>1$ were significantly associated with poor prognosis for both OS and PFS (monocyte ratio $>1$, hazard ratio $1.999,95 \%$ CI 1.141-3.504, $p=0.016$; hazard ratio $1.628,95 \%$ CI $1.080-2.455, p=0.02$, respectively) and (NLR ratio $>1$, hazard ratio $2.477,95 \%$ CI $1.423-4.311$, $p=0.001$; hazard ratio $1.531,95 \%$ CI $1.035-2.265$, $p=0.033$, respectively). Patients were then divided into four categories according to different monocyte ratio and NLR ratio (group 1, monocyte ratio $<=1$ and NLR ratio $<=1(n=76,53.5 \%)$; group 2 , monocyte ratio $<=1$ and NLR ratio $>1(n=23,16.2 \%)$; group 3, monocyte ratio $>1$ and NLR ratio $<=1(n=13,9.2 \%)$; and group 4 , monocyte ratio $>1$ and NLR ratio $>1(n=30,21.1 \%))$ to evaluate their combining prognostic value on both OS and
PFS (Fig. 4). Accordingly, patients in group 1 showed significant better OS than patients in all the other 3 groups.

\section{DISCUSSION}

This series of patients represents a single-institution nearly 50-year experience in the management of metastatic STS. As an important subgroup of STS [21, 22], metastatic STS still have an unsatisfying prognosis, despite of continuous treatment development [23-25]. Similar to localized disease, metastatic STS incorporates heterogeneous groups with different pathological subtypes or tumor sites, which result in broad prognostic spectrums. Previous studies reported little prognosis improvement of metastatic STS in last decades [23-25]. This is why we set out to determine whether possible risk factors, such as age, sex, primary tumor site, size of primary tumor, tumor depth, pathological subtypes, pathological grade, Monocyte ratio or NLR ratio, could predict either PFS or OS in patients with metastatic STS.

Publications have already shown that both the intrinsic characteristics and environment of tumor affected the invaded and metastatic ability [26]. Abnormal tumor phenotype may stimulate inflammatory cells flowing into tissues around the tumor. In addition, generalized and nonspecific inflammatory response could be triggered by generalized and nonspecific inflammatory response and following tissue destruction and disruption [27]. Evidence indicated an association among systemic inflammatory response, progressive nutritional and functional decline in cancer victims, and poor prognosis, which could be partly interpreted by insidious cancer progression activating innate immunity $[10,28]$.

A correlation between the increasing monocytes, neutrophils and decreasing lymphocytes and inflammationinduced tumor growth and progression via various growth 

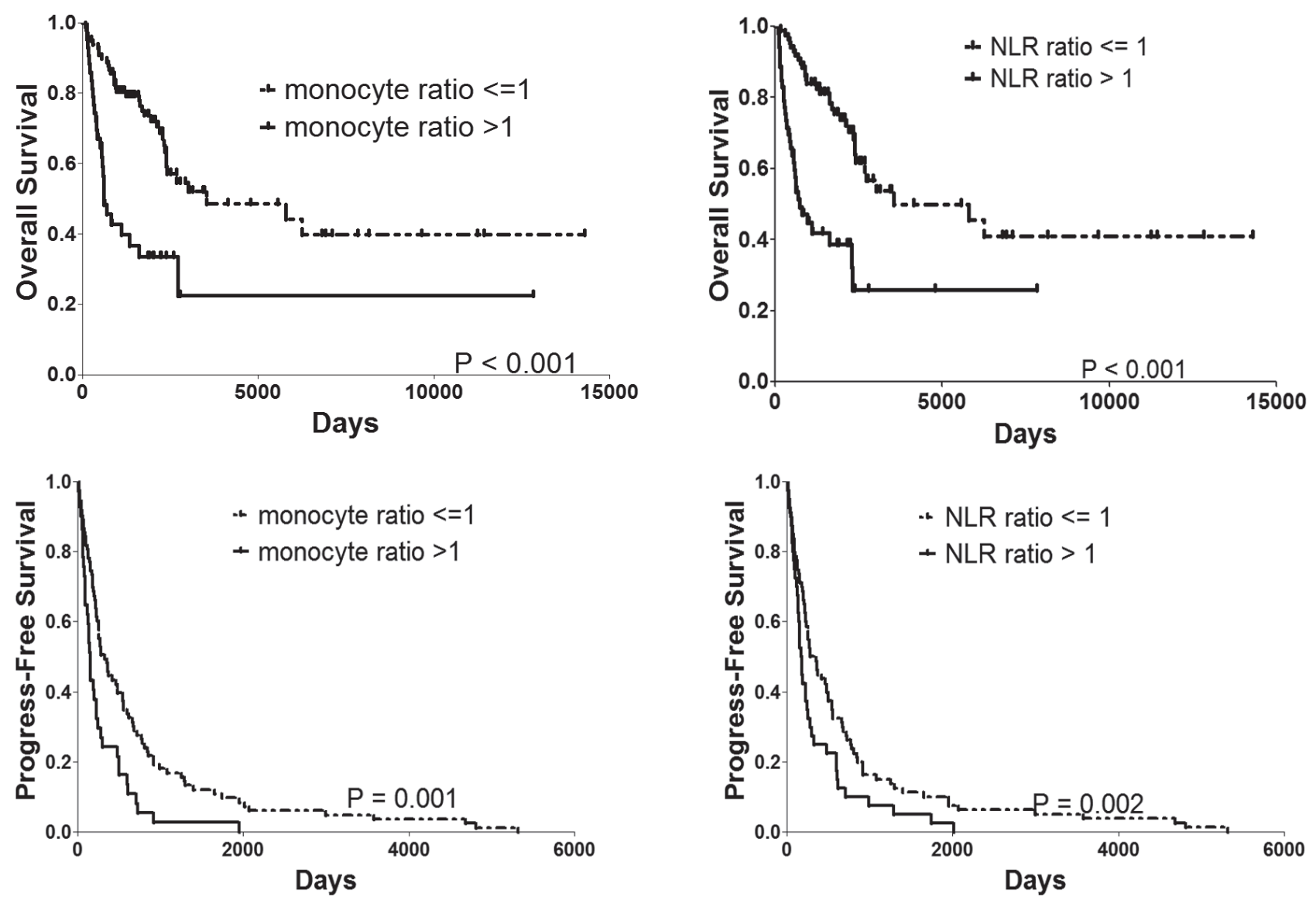

Figure 3: OS and PFS rate of patients with monocyte ratio $>1$ vs. $<=1$ and NLR ratio $>1$ vs. $<=1$. PFS progress-free survival, OS overall survival.

Table 3: Multivariable analysis of prognostic factors for OS and PFS in patients with Metastatic STS

\begin{tabular}{|c|c|c|c|c|c|c|}
\hline \multirow{2}{*}{ Variables } & \multicolumn{3}{|c|}{ OS } & \multicolumn{3}{|c|}{ PFS } \\
\hline & HR & $95 \%$ CI & $P$ value & HR & $95 \%$ CI & $P$ value \\
\hline $\begin{array}{l}\text { PFS exceeding } \\
225 \text { days }\end{array}$ & 0.553 & $0.330-0.927$ & 0.025 & & & \\
\hline monocyte ratio $>1$ & 1.999 & $1.141-3.504$ & 0.016 & 1.628 & $1.080-2.455$ & 0.020 \\
\hline NLR ratio > 1 & 2.477 & $1.423-4.311$ & 0.001 & 1.531 & $1.035-2.265$ & 0.033 \\
\hline
\end{tabular}

and pro-angiogenic cytokines has been observed and proved, although immunosuppression is common in the cancer population [29-33].

Studies have showed peripheral blood monocytes to be an independent prognosis factor in patients with neck and head, biliary, cervix, liver, stomach and colon cancers [19, 31, 34-36]. Low blood neutrophil count and high lymphocyte count showed prognostic value in several studies [34, 37-39]. In addition, various evidences indicated elevating NLR accompanying poor prognosis in hepatocellular carcinoma, ovarian cancer, colorectal cancers, gastric cancer, and head and neck cancer $[13,16$, $35,40,41]$. Investigations revealed that this association might be caused by suppressed antitumor cellular immune activity of natural killer cells and lymphocyte by increased neutrophils [38]. Previous studies on circulating leukocyte influenced us concerning the association between clinical circulating monocytes, neutrophils, lymphocytes and tumor prognosis. Differently, relative large number of patients with metastatic STS were enrolled in current 

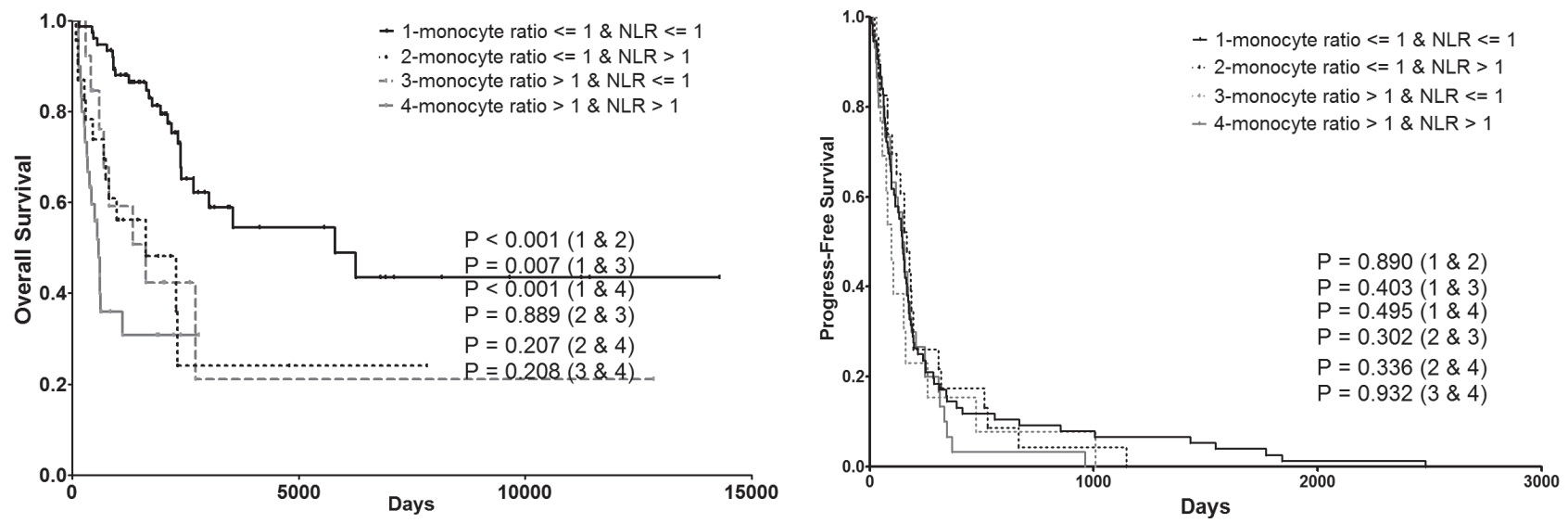

Figure 4: Combining prognostic value of monocyte ratio and NLR ratio on both OS and PFS. PFS progress-free survival, OS overall survival.

study. Furthermore, monocyte and NLR ratio, instead of cells counts, were used in our analysis, which could assess the impact of response to treatment.

Sarcomas, since at least as far back as 1891 , have been suspected to have a relationship to the immune system [42]. Many sarcomas express highly immunogenic antigens, such as neo-antigens from specific translocations, cancer/testis antigens and microphthalmia transcription factor, and even the fusion proteins themselves, which could be seen as foreign by immune system and used as target of immunotherapy [43-45]. Over the past several years, various advances including tumor vaccination, adoptive cell transfer, biochemotherapy, and immune checkpoint blockade are rapidly emerging and benefiting sarcoma patients [46-48]. Preliminary result of dendritic cell vaccines suggested the tolerance and inducing immune response of tumor vaccination. Recombinant NY-ESO-1 intranodal injection before sirolimus indicated superior anti-tumor efficacy of mTOR inhibition through promoting CD8+ T-cell memory responses [49]. Takahashi treated 20 refractory sarcoma patients by employing 15 tumor-associated antigens with totally 31 peptides [50]. An objective clinical response in four of six patients with synovial cell sarcoma was obtained after adoptive transfer of autologous T-cells transduced with TCR against NYESO-1 [44]. One patient with epithelioid sarcoma was reported to be treated with expanded lymphocytes and natural killer cells [51]. Interleukin-2 therapy was used in angiosarcoma, although results of clinical trials were not yet available [52]. Ipilimumab, anti-CTLA-4 antibody, was halted for poor accrual in synovial sarcoma in a previous study [53]. Clinical trials of sarcoma-specific PD-1 targeted agents are still in the planning stages [54].

Several limitations remain in this study. First, all the data were retrospectively collected, thus clinical and survival comparison might be influenced by selection bias due to its retrospective nature. Second, a relatively small number of each histologic subtype was examined in this study, due to the reason that metastatic STS are extremely rare. It is substantial that the result of histologic subtypes not predicting PFS or OS might be caused by a Type II error. Although, we have enrolled sufficient number of metastatic STS to identify differences in other prognostic factors. Third, the monocyte phenotype or molecular information were not analyzed, which was cause by lack of these information in our retrospective data. Fourth, other systemic inflammatory immune index, such as C-reactive protein or albumin, which were known as prognostic factors [55], also absent in our retrospective data.

\section{MATERIALS AND METHODS}

This study was approved by the institutional review board of Sun Yat-sen University Cancer Center (SYSUCC) and informed consent was obtained from each participant. Chart review was performed on 154 consecutive patients who suffered from STS with metastases between July 1965 and May 2013. Only patients with metastatic STS were included in current study, whereas those with osteosarcoma were not. Under these criteria, 142 of the 154 patients were enrolled in the final analysis. 12 patients with STS were excluded from analysis because of incomplete records. Characteristics of patients and tumors at initial diagnosis of STS and development of metastases were collected and tested for relationships with progress free survival (PFS) and overall survival (OS). The following factors were studied: patient age, sex (male vs. female), primary tumor size, and tumor depth (superficial vs. deep) at diagnosis. WHO classification [20] was used for determination of pathological diagnosis and tumor grade. All data were reviewed and confirmed by two independent pathologists.

Monocyte ratio was calculated as absolute monocyte count after initial treatment divided by absolute monocyte count before initial treatment. NLR was calculated as 
neutrophil count divided by lymphocyte count. NLR ratio was calculated as NLR after initial treatment divided by NLR before initial treatment. The blood tests were obtained within 24 hours for all patients as routine clinical practice in SYSUCC.

\section{Statistical analysis}

The data are presented as the number $(\%)$ or median (range) unless otherwise stated. The Pearson $\chi 2$ test and Fisher's exact test were used for categorical data, and an independent sample $t$-test or the Mann-Whitney $U$ test were used for numerical data.

PFS and OS curves were estimated using the KaplanMeier method. PFS was calculated from the date of initial diagnosis to the time of metastasis diagnosis, and OS from the date of initial diagnosis to the time of death reported. Risk factors of PFS and OS were assessed by univariate analysis with log rank test and multivariate analysis with Cox proportional hazards regression. Multivariate analysis was performed using Cox proportional hazard model. Cut-off value of PFS was established by the receiver operating characteristic (ROC) curve statistical analyses. All models for survival analyses were adjusted for age at diagnosis. $P<0.05$ was considered to be significant in all statistical analyses. Data analysis was performed using SPSS 18.0 (PASW Statistics 18) for Windows (SPSS Inc, Chicago, IL).

\section{CONCLUSION}

In current study, both monocyte ratio and NLR ratio were found to be significant prognostic predictors for OS and PFS of metastatic STS. Additionally, it was strongly believed that patients with monocyte ratio or NLR ratio $>1$ should be screened out as candidates for more intensive or aggressive multimodality treatments and more aggressive follow-up. For this reason, this result could serve as a basis for future prospective study in selecting high risk patients for candidates for more aggressive multimodality treatments and more intensive follow-up and setting up a predicting model by subtyping the populations of monocytes or lymphocytes.

\section{CONFLICTS OF INTEREST}

The authors declare no competing interests.

\section{REFERENCES}

1. Siegel R, Ma J, Zou Z, Jemal A. Cancer statistics. CA Cancer J Clin. 2014; 64:9-29.

2. Ludwig JA. Ewing sarcoma: historical perspectives, current state-of-the-art, and opportunities for targeted therapy in the future. Curr Opin Oncol. 2008; 20:412-418.
3. Cotterill SJ, Ahrens S, Paulussen M, Jurgens HF, Voute PA, Gadner H, Craft AW. Prognostic factors in Ewing's tumor of bone: analysis of 975 patients from the European Intergroup Cooperative Ewing's Sarcoma Study Group. J Clin Oncol. 2000; 18:3108-3114.

4. Subbiah V, Anderson P, Lazar AJ, Burdett E, Raymond K, Ludwig JA. Ewing's sarcoma: standard and experimental treatment options. Curr Treat Options Oncol. 2009; 10:126-140.

5. Corey RM, Swett K, Ward WG. Epidemiology and survivorship of soft tissue sarcomas in adults: a national cancer database report. Cancer Med. 2014; 3:1404-1415.

6. Briccoli A, Rocca M, Salone M, Bacci G, Ferrari S, Balladelli A, Mercuri M. Resection of recurrent pulmonary metastases in patients with osteosarcoma. Cancer. 2005; 104:1721-1725.

7. Tsuchiya H, Kanazawa Y, Abdel-Wanis ME, Asada N, Abe S, Isu K, Sugita T, Tomita K. Effect of timing of pulmonary metastases identification on prognosis of patients with osteosarcoma: the Japanese Musculoskeletal Oncology Group study. J Clin Oncol. 2002; 20:3470-3477.

8. Kempf-Bielack B, Bielack SS, Jurgens H, Branscheid D, Berdel WE, Exner GU, Gobel U, Helmke K, Jundt G, Kabisch H, Kevric M, Klingebiel T, Kotz R, Maas R, Schwarz R, Semik M, et al. Osteosarcoma relapse after combined modality therapy: an analysis of unselected patients in the Cooperative Osteosarcoma Study Group (COSS). J Clin Oncol. 2005; 23:559-568.

9. Carter SR, Grimer RJ, Sneath RS, Matthews HR. Results of thoracotomy in osteogenic sarcoma with pulmonary metastases. Thorax. 1991; 46:727-731.

10. McMillan DC. Systemic inflammation, nutritional status and survival in patients with cancer. Curr Opin Clin Nutr Metab Care. 2009; 12:223-226.

11. Roxburgh CS, McMillan DC. Role of systemic inflammatory response in predicting survival in patients with primary operable cancer. Future Oncol. 2010; 6:149-163.

12. Satomi A, Murakami S, Ishida K, Mastuki M, Hashimoto T, Sonoda M. Significance of increased neutrophils in patients with advanced colorectal cancer. Acta Oncol. 1995; 34:69-73.

13. Walsh SR, Cook EJ, Goulder F, Justin TA, Keeling NJ. Neutrophil-lymphocyte ratio as a prognostic factor in colorectal cancer. J Surg Oncol. 2005; 91:181-184.

14. Sarraf KM, Belcher E, Raevsky E, Nicholson AG, Goldstraw P, Lim E. Neutrophil/lymphocyte ratio and its association with survival after complete resection in nonsmall cell lung cancer. J Thorac Cardiovasc Surg. 2009; 137:425-428.

15. Halazun KJ, Aldoori A, Malik HZ, Al-Mukhtar A, Prasad KR, Toogood GJ, Lodge JP. Elevated preoperative neutrophil to lymphocyte ratio predicts survival following hepatic resection for colorectal liver metastases. Eur J Surg Oncol. 2008; 34:55-60. 
16. Gomez D, Farid S, Malik HZ, Young AL, Toogood GJ, Lodge JP, Prasad KR. Preoperative neutrophil-tolymphocyte ratio as a prognostic predictor after curative resection for hepatocellular carcinoma. World J Surg. 2008; 32:1757-1762.

17. Shau HY, Kim A. Suppression of lymphokine-activated killer induction by neutrophils. J Immunol. 1988; 141:4395-4402.

18. Sasaki A, Iwashita Y, Shibata K, Matsumoto T, Ohta M, Kitano S. Prognostic value of preoperative peripheral blood monocyte count in patients with hepatocellular carcinoma. Surgery. 2006; 139:755-764.

19. Sasaki A, Kai S, Endo Y, Iwaki K, Uchida H, Tominaga M, Okunaga R, Shibata K, Ohta M, Kitano S. Prognostic value of preoperative peripheral blood monocyte count in patients with colorectal liver metastasis after liver resection. J Gastrointest Surg. 2007; 11:596-602.

20. Rosenberg AE. WHO Classification of Soft Tissue and Bone, fourth edition: summary and commentary. Curr Opin Oncol. 2013; 25:571-573.

21. Breneman JC, Lyden E, Pappo AS, Link MP, Anderson JR, Parham DM, Qualman SJ, Wharam MD, Donaldson SS, Maurer HM, Meyer WH, Baker KS, Paidas CN, Crist WM. Prognostic factors and clinical outcomes in children and adolescents with metastatic rhabdomyosarcoma - a report from the Intergroup Rhabdomyosarcoma Study, IV. J Clin Oncol. 2003; 21:78-84.

22. Rodeberg D, Arndt C, Breneman J, Lyden E, Donaldson S, Paidas C, Andrassy R, Meyer W, Wiener E. Characteristics and outcomes of rhabdomyosarcoma patients with isolated lung metastases from IRS-IV. J Pediatr Surg. 2005; 40:256-262.

23. Koscielniak E, Harms D, Henze G, Jurgens H, Gadner H, Herbst M, Klingebiel T, Schmidt BF, Morgan M, Knietig R, Treuner J. Results of treatment for soft tissue sarcoma in childhood and adolescence: a final report of the German Cooperative Soft Tissue Sarcoma Study CWS-86. J Clin Oncol. 1999; 17:3706-3719.

24. Carli M, Colombatti R, Oberlin O, Bisogno G, Treuner J, Koscielniak E, Tridello G, Garaventa A, Pinkerton R, Stevens M. European intergroup studies (MMT4-89 and MMT4-91) on childhood metastatic rhabdomyosarcoma: final results and analysis of prognostic factors. J Clin Oncol. 2004; 22:4787-4794.

25. Crist W, Gehan EA, Ragab AH, Dickman PS, Donaldson SS, Fryer C, Hammond D, Hays DM, Herrmann J, Heyn R, Et A. The Third Intergroup Rhabdomyosarcoma Study. J Clin Oncol. 1995; 13:610-630.

26. Coussens LM, Werb Z. Inflammation and cancer. Nature. 2002; 420:860-867.

27. Nagtegaal ID, Marijnen CA, Kranenbarg EK, MulderStapel A, Hermans J, van de Velde CJ, van Krieken JH. Local and distant recurrences in rectal cancer patients are predicted by the nonspecific immune response; specific immune response has only a systemic effect - a histopathological and immunohistochemical study. Bmc Cancer. 2001; 1:7.

28. Droin N, Hendra JB, Ducoroy P, Solary E. Human defensins as cancer biomarkers and antitumour molecules. J Proteomics. 2009; 72:918-927.

29. Wong CP, Bray TM, Ho E. Induction of proinflammatory response in prostate cancer epithelial cells by activated macrophages. Cancer Lett. 2009; 276:38-46.

30. Ishigami S, Natsugoe S, Tokuda K, Nakajo A, Okumura H, Matsumoto M, Miyazono F, Hokita S, Aikou T. Tumorassociated macrophage (TAM) infiltration in gastric cancer. Anticancer Res. 2003; 23:4079-4083.

31. Lin JY, Li XY, Tadashi N, Dong P. Clinical significance of tumor-associated macrophage infiltration in supraglottic laryngeal carcinoma. Chin J Cancer. 2011; 30:280-286.

32. Belge KU, Dayyani F, Horelt A, Siedlar M, Frankenberger M, Frankenberger B, Espevik T, Ziegler-Heitbrock L. The proinflammatory CD14+CD16+DR++ monocytes are a major source of TNF. J Immunol. 2002; 168:3536-3542.

33. Budhu A, Forgues M, Ye QH, Jia HL, He P, Zanetti KA, Kammula US, Chen Y, Qin LX, Tang ZY, Wang XW. Prediction of venous metastases, recurrence, and prognosis in hepatocellular carcinoma based on a unique immune response signature of the liver microenvironment. Cancer Cell. 2006; 10:99-111.

34. Bruckner HW, Lavin PT, Plaxe SC, Storch JA, Livstone EM. Absolute granulocyte, lymphocyte, and moncyte counts. Useful determinants of prognosis for patients with metastatic cancer of the stomach. JAMA. 1982; 247:1004-1006.

35. Elias EG, Leuchten JM, Buda BS, Brown SD. Prognostic value of initial mononucleated cell percentages in patients with epidermoid carcinoma of the head and neck. Am J Surg. 1986; 152:487-490.

36. Subimerb C, Pinlaor S, Lulitanond V, Khuntikeo N, Okada S, McGrath MS, Wongkham S. Circulating CD14(+) CD16(+) monocyte levels predict tissue invasive character of cholangiocarcinoma. Clin Exp Immunol. 2010; 161:471-479.

37. Shamamian P, Schwartz JD, Pocock BJ, Monea S, Whiting D, Marcus SG, Mignatti P. Activation of progelatinase A (MMP-2) by neutrophil elastase, cathepsin G, and proteinase-3: a role for inflammatory cells in tumor invasion and angiogenesis. J Cell Physiol. 2001; 189:197-206.

38. Petrie HT, Klassen LW, Kay HD. Inhibition of human cytotoxic T lymphocyte activity in vitro by autologous peripheral blood granulocytes. J Immunol. 1985; 134:230-234.

39. El-Hag A, Clark RA. Immunosuppression by activated human neutrophils. Dependence on the myeloperoxidase system. J Immunol. 1987; 139:2406-2413.

40. Cho H, Hur HW, Kim SW, Kim SH, Kim JH, Kim YT, Lee K. Pre-treatment neutrophil to lymphocyte ratio is 
elevated in epithelial ovarian cancer and predicts survival after treatment. Cancer Immunol Immunother. 2009; 58:15-23.

41. Yamanaka T, Matsumoto S, Teramukai S, Ishiwata R, Nagai Y, Fukushima M. The baseline ratio of neutrophils to lymphocytes is associated with patient prognosis in advanced gastric cancer. Oncology-Basel. 2007; 73:215-220.

42. Coley WB II. Contribution to the Knowledge of Sarcoma. Ann Surg. 1891; 14:199-220.

43. Dagher R, Long LM, Read EJ, Leitman SF, Carter CS, Tsokos M, Goletz TJ, Avila N, Berzofsky JA, Helman LJ, Mackall CL. Pilot trial of tumor-specific peptide vaccination and continuous infusion interleukin-2 in patients with recurrent Ewing sarcoma and alveolar rhabdomyosarcoma: an inter-institute NIH study. Med Pediatr Oncol. 2002; 38:158-164.

44. Robbins PF, Morgan RA, Feldman SA, Yang JC, Sherry RM, Dudley ME, Wunderlich JR, Nahvi AV, Helman LJ, Mackall CL, Kammula US, Hughes MS, Restifo NP, Raffeld M, Lee CC, Levy CL, et al. Tumor regression in patients with metastatic synovial cell sarcoma and melanoma using genetically engineered lymphocytes reactive with NY-ESO-1. J Clin Oncol. 2011; 29:917-924.

45. Rosenberg SA, Yang JC, Restifo NP. Cancer immunotherapy: moving beyond current vaccines. Nat Med. 2004; 10:909-915.

46. Dranoff G. GM-CSF-based cancer vaccines. Immunol Rev. 2002; 188:147-154.

47. Strbo N, Podack ER. Secreted heat shock protein gp96-Ig: an innovative vaccine approach. Am J Reprod Immunol. 2008; 59:407-416.
48. Dranoff G. CTLA-4 blockade: unveiling immune regulation. J Clin Oncol. 2005; 23:662-664.

49. Li Q, Rao R, Vazzana J, Goedegebuure P, Odunsi K, Gillanders W, Shrikant PA. Regulating mammalian target of rapamycin to tune vaccination-induced CD8(+) $\mathrm{T}$ cell responses for tumor immunity. J Immunol. 2012; 188:3080-3087.

50. Takahashi R, Ishibashi Y, Hiraoka K, Matsueda S, Kawano K, Kawahara A, Kage M, Ohshima K, Yamanaka R, Shichijo S, Shirouzu K, Itoh K, Sasada T. Phase II study of personalized peptide vaccination for refractory bone and soft tissue sarcoma patients. Cancer Sci. 2013; 104:1285-1294.

51. Ratnavelu K, Subramani B, Pullai CR, Krishnan K, Sugadan SD, Rao MS, Veerakumarasivam A, Deng X, Hiroshi T. Autologous immune enhancement therapy against an advanced epithelioid sarcoma: A case report. Oncol Lett. 2013; 5:1457-1460.

52. Noguchi G, Ota J, Ishigaki H, Onuki T, Kato Y, Moriyama M. Nihon Hinyokika Gakkai Zasshi. 2012; 103:697-703.

53. Maki RG, Jungbluth AA, Gnjatic S, Schwartz GK, D'Adamo DR, Keohan ML, Wagner MJ, Scheu K, Chiu R, Ritter E, Kachel J, Lowy I, Old LJ, Ritter G. A Pilot Study of Anti-CTLA4 Antibody Ipilimumab in Patients with Synovial Sarcoma. Sarcoma. 2013; 2013:168145.

54. Wilky BA, Goldberg JM. Immunotherapy in sarcoma: a new frontier. Discov Med. 2014; 17:201-206.

55. Crozier JE, McKee RF, McArdle CS, Angerson WJ, Anderson JH, Horgan PG, McMillan DC. Preoperative but not postoperative systemic inflammatory response correlates with survival in colorectal cancer. Br J Surg. 2007; 94:1028-1032. 